ББК 63.4

\author{
Организация конференциии и издание материалов проведень \\ при финансовой поддержке Российского фонда фундаментальных исследований, \\ проект № 19-09-20008
}

Утверждено к печати Ученым советом ИИМК РАН

Редакционная коллегия тома I: В. А. Алёкшин, Л. Б. Кирчо (отв. редакторы),

В. П. Никоноров, В. Я. Стёганцева; В. В. Терёхина

Рецензенты: д. и. н. Л. Б. Вишняцкий, д. и. н. А. А. Выборнов

Программный комитет конференции: академик РАН, д. и. н., проф. М. Б. Пиотровский

(Государственный Эрмитаж, почетный председатель); д. и. н. В. А. Лапшин (ИИМК РАН, председатель); д. и. н. А. В. Головнёв (МАЭ РАН, сопредседатель); д. и. н. В. А. Дергачёв (Высшая антропологическая школа, Молдова, сопредседатель); д. и. н. И. Ф. Попова (ИВР РАН, сопредседатель); академик АН Республики Узбекистан, д. и. н., проф. Э. В. Ртвеладзе (сопредседатель); к. и. н. А. В. Поляков (ИИМК РАН, зам. председателя); к. и. н. В. А. Алёкшин (ИИМК РАН, зам. председателя); д. и. н. Ю. Е. Берёзкин (МАЭ РАН); Dr., Prof. Н. Бороффка (Германский археологический институт, Германия); В. С. Бочкарёв (ИИМК РАН); Dr. Э. Кайзер (Свободный университет Берлина, Германия); к. и. н. М. Т. Кашуба (ИИМК РАН); д. и. н. Л. Б. Кирчо (ИИМК РАН); к. и. н. А. В. Кияшко (Южный федеральный университет); к. и. н. П. Ф. Кузнецов (СГСПУ);

к. и. н. Н. М. Малов (СНИГУ); к. и. н. В. П. Никоноров (ИИМК РАН); Ю. Ю. Пиотровский

(Государственный Эрмитаж); д. и. н., проф. Д. Г. Савинов (Институт истории СПбГУ);

к. и. н. В. Н. Седых (Институт истории СПбГУ); к. и. н. Н. Н. Скакун (ИИМК РАН);

к. и. н. Н. Ф. Соловьёва (ИИМК РАН); к. и. н. А. И. Торгоев (Государственный Эрмитаж); к. и. н. Е. А. Черлёнок (Институт истории СПбГУ)

Организационный комитет конференции: к. и. н. А. В. Поляков (ИИМК РАН, председатель);

к. и. н. В. А. Алёкшин (ИИМК РАН, зам. председателя); В. С. Бочкарёв (ИИМК РАН); ); к. и. н. М. Т. Кашуба (ИИМК РАН); д. и. н. Л. Б. Кирчо (ИИМК РАН);

А. И. Климушина (ИИМК РАН, отв. секретарь); к. и. н. В. П. Никоноров (ИИМК РАН); Ю. Ю. Пиотровский (Государственный Эрмитаж); В. Я. Стёганцева (ИИМК РАН); В. В. Терёхина

(ИИМК РАН, МАЭ РАН, отв. секретарь); к. и. н. Е. С. Ткач (ИИМК РАН); И. Ж. Тутаева (Государственный Эрмитаж); к. и. н. Е. А. Черлёнок (Институт истории СПбГУ)

Древности Восточной Европы, Центральной Азии и Южной Сибири в контексте связей и взаимодействий в евразийском культурном пространстве (новые данные и концепции): Материалы Международной конференции, 18-22 ноября 2019 г., Санкт-Петербург. Т. I. Древняя Центральная Азия в контексте евразийского культурного пространства (новые данные и концепции). К 90-летию со дня рождения патриарха евразийской археологии Вадима Михайловича Массона. - СПб.: ИИМК РАН, Невская Типография, 2019. — 291 с.

ISBN 978-5-907053-34-2

DOI 10.31600/978-5-907053-34-2 
железоплавильных шлаков с точки зрения минералогии, фазовых состояний и их химического состава для определения специфической техники получения металла. Результаты этого изучения показывают, что образцы из Харрехсее в основном являются железистыми шлаками, полученными в результате обработки железа в восстановительной печи. Кроме того, основываясь на фазах, которые обнаруживаются в шлаковой смеси, высказывается предположение, что система получения железа в этом регионе базировалась на технологии использования открытых печей и высоких температур - около 1100-1220 $\mathrm{C}$.

\title{
REDEFINE THE IDEA OF BMAC THROUGH THE LAST INNOVATIVE DATA OF THE LATE BRONZE AGE MARGIANA
}

\author{
Barbara Cerasetti \\ University of Bologna, Bologna, Italy
}

DOI: $10.31600 / 978-5-907053-34-2-79-80$

Keywords: Central Asia, Turkmenistan, Late Bronze Age, Bactria-Margiana archaeological complex (BMAC), Togolok.

Central Asia's Bronze-Iron Age transition during the $2^{\text {nd }}$ mil. BCE is bookended by the urban fluorescence of the Bactria-Margiana archaeological complex (BMAC) and the re-emergence of urban centers that would eventually be subsumed into the Achaemenid Empire. The intervening period (Late and Final Bronze Ages, ca. 1950-1300 BCE) has been described as one of deurbanization, collapse, and decay of the BMAC socio-political and cultural system, meanwhile other scholars view the changes of the Late/Final Bronze Ages as an untroubled continuation.

There are three key issues that drive the still-underdeveloped scholarship on the dissolution of the BMAC in the $2^{\text {nd }}$ millennium BCE. The first is the position of the BMAC vis-à-vis its regional contemporaries and economic partners in the Indus Valley, the Iranian plateau, the Arabian Peninsula, and Mesopotamia. Their fragmentation in the early $2^{\text {nd }}$ millennium BCE no doubt influenced BMAC decline, but the mechanism of this economic and political transformation remain poorly understood. A second issue often tied into discussions of BMAC decline is the apparent intensification of interactions between established sedentary farming communities and non-local agropastoralists linked to the Andronovo cultural community of Bronze Age Central Eurasia. Lastly, chronological issues overshadow all other archaeological inquiries on this period, whose unclear timescales are difficult to reckon with the archaeological record. All three of these interrelated issues can potentially be addressed through deep stratigraphic study of a single longlived BMAC site as Togolok, with the hope to clarify how BMAC related to earlier and later occupation in ancient Margiana.

\section{ПЕРЕОСМЫСЛЕНИЕ ИДЕИ ВМАК С ПОМОЩЬЮ ПОСЛЕДНИХ ИННОВАЦИОННЫХ ДАННЫХ О ПОЗДНЕМ БРОНЗОВОМ ВЕКЕ МАРГИАНЫ}

\author{
Барбара Черазетти \\ Болонский университет, Болонья, Италия
}

Ключевые слова: Центральная Азия, Туркменистан, эпоха поздней бронзы, бактрийскомаргианский археологический комплекс (БМАК), Тоголок.

Переходный период бронзового века в Центральной Азии во II в. тыс. до н. э. отмечается расцветом городской культуры бактрийско-маргианского археологического комплекса (БМАК) и возрождением городских центров. Промежуточный этап (поздний и финальный бронзовый век, около 1950-1300 гг. до н.э.) описан как де-урбанизация, коллапс и упадок 
социально-политической и культурной системы ВМАК, тогда как другие ученые рассматривают изменения позднего/финального бронзового века как вполне спокойное продолжение предыдущего историко-культурного развития.

Есть три ключевых вопроса относительно упадка БМАК во ІІ тыс. до н. э. Первым является позиция БМАК по отношению к его региональным современникам и экономическим партнерам в долине Инда, на Иранском плато, Аравийском п-ове и в Месопотамии. Их раздробленность в начале II тыс. до н. э., несомненно, повлияла на упадок БМАК, но механизм этой экономической и политической трансформации остается недостаточно изученным. Второй проблемой, часто связанной с дискуссиями об упадке БМАК, является очевидная интенсификация взаимодействий между устоявшимися оседлыми земледельческими общинами и неместным агро-пастушеским населением, связанным с андроновской культурной общностью бронзового века Центральной Евразии. Наконец, хронологические проблемы оставляют в тени все другие археологические изыскания по этому периоду, чьи неясные временные рамки трудно соотнести с археологическими данными. Все три из этих взаимосвязанных проблем потенциально могут быть решены путем глубокого стратиграфического исследования такого долго существовавшего поселения БМАК, как Тоголок, что позволит прояснить, как БМАК связан с более ранним и более поздним периодами проживания людей в Древней Маргиане.

\title{
ИССЛЕДОВАНИЕ ТЕХНИКИ МОЗАИЧНОГО ДЕКОРА КОНЦА ІІІ ТЫС. ДО Н. Э. ИЗ «ЦАРСКИХ» ГРОБНИЦ ГОНУР-ДЕПЕ
}

\author{
Г. Э. Вересоцкая, А. Я. Мазина ${ }^{* *}$ \\ ${ }^{*}$ Государственный научно-исследовательский институт реставрации, Москва, \\ Россия; ${ }^{* *}$ Всероссийский художественный научно-реставрационный иентр \\ им. акад. И. Э. Грабаря, Москва, Россия
}

DOI: 10.31600/978-5-907053-34-2-80-81

Ключевые слова: Туркменистан, Маргианская археологическая экспедиция, Гонур-депе, «Царский» некрополь, исследования технологии, мозаичный декор.

При раскопках первых элитарных гробниц на Гонуре были обнаружены многочисленные фрагменты мозаичного декора (см., например: Сарианиди, Дубова 2013). В основном, это были отдельные элементы в разрозненном состоянии, которые «буквально высыпались из песчаного заполнения, <...> был также раскрыт целый фриз длиной 86 см, изображающий чередующиеся пары крылатых львов <... с вздыбленными загривками и оскаленными зубастыми пастями. Было найдено и более крупное, включенное в картуш, изображение крылатого льва с рогом на носу и заостренной, извивающейся бородкой» (Сарианиди 2008: 214-220).

Особенно ценными находками являются сохранившиеся фрагменты мозаичных сюжетных и орнаментальных композиций, выполненные в смешанной технике мозаики и полихромной росписи, обнаруженные in situ в погребениях № 3210, 3230, 3220 и 3880 . Поражает разнообразие сюжетов и художественная зрелость этих древних произведений. Техника исполнения мозаик удивляет точностью обработки деталей и сложной технологией изготовления.

Первые исследования материалов мозаик были проведены в 2004 г. в Германии (Экспертное заключение... 2012) и А. М. Юминовым (Институт минералогии УрО РАН, г. Миасс). «Судя по минеральному составу и структурно-текстурным особенностям материала, для производства мозаичных плиток в качестве сырья могли быть использованы 